Tímár Krisztina:

\title{
Kant etikai formalizmusának kiindulópontja
}

Ha azt szeretnénk számba venni, hányan interpretálták és bírálták már Kant etikáját, meglehetősen nehéz dolgunk lenne, hiszen 1785 óta a reflexiók és bírálatok szinte végtelenül hosszú sora látott már napvilágot, feldolgozásuk gigászi feladatnak tünik, s így nem is vállalkozhatunk rá. Ha azonban annak körvonalazását tüznénk ki célul, milyen megfontolások szolgáltak illetve szolgálnak e kritikák alapjául, már határozottabbak lehetnénk, hiszen az egyik legmarkánsabb támadási pont a königsbergi filozófus ellen minden bizonnyal nem más, mint az üresnek és semmitmondónak bélyegzett formalizmus.

Dolgozatomban azt szeretném megvizsgálni, vajon miért és hogyan lépett Kant az etikában a formalizmus radikálisan új ösvényére, amely a késóbbiekben e rengeteg kritikát kiváltotta. Arra a kérdésre szeretnék választ kapni, vajon Kant miért érezte szükségét annak, hogy a korábban felmerülő tartalmi etikákat félretéve egy tisztán formális megoldást dolgozzon ki, és vajon mi volt az a sajátos kiindulópont, amely elődeinél hiányzott, $\mathrm{s}$ ami így egyrészt rámutatott a korábbi etikák elégtelenségére, másrészt pedig az új megoldási kísérlet felvázolásának alapjául is szolgálhatott Vizsgálódásaim célja nem Kant fejtegetéseinek átfogó bemutatása, hanem csupán annak a fordulópontnak a körüljárása, amely oly élesen elválasztja ezt a rendszert az összes többitól.

\section{Az etikai formalizmus elôzményei A tiszta ész kritikájában}

Kant etikai múveiben gyakran hangsúlyozza azt a szóban forgó elképzelést, amely egyfelól a korábbi elméletekben felmerülő alternatívák elutasításának, másfelól pedig saját etikai formalizmusának alapját képezi. Ez a kiindulópont valójában nem másban, mint az erkölcsi törvénnyel szemben támasztott sajátos követelményekben ölt testet: ezen követelmények szerint az erkölcsi törvénynek univerzálisnak és szükségszerünek kell lennie. Kant ebból a számára egyértelmú tételból indul ki, $\mathrm{s}$ fejti ki etikai rendszerének legfontosabb fogalmait, a jó akaratot, a kötelességet, a kategorikus imperatívuszt, az autonómiát és a szabadságot.

$\mathrm{Az}$ univerzális és szükségszerű erkölcsi törvény vizsgálata sajátos módszert igényel, vagyis ez egy olyan vállalkozás, amelyhez nem foghatunk hozzá akárhogyan. Erre utalva Kant két részt különböztet meg az etikán belül: a tiszta és az empirikus részt. $\mathrm{Az}$ utóbbi a gyakorlati antropológiát foglalja magába, az elóbbi pedig a "tiszta morálfilozófia", "az erkölcsök metafizikájának" terrénuma - Kant szerint csak itt lehetséges az univerzálisnak és szükségszerünek feltételezett erkölcsi törvény felkutatása és bármiféle vizsgálata.

A königsbergi filozófus tehát minden korábbi etikai megfontolástól eltérően az erkölcsök metafizikájáról beszél, s ehhez az erkölcsi törvénnyel szemben felállított követelményei révén jut el - a kérdés az, hogy hogyan.

A szükségszerúség és az egyetemesség gondolata nem etikai múveiben jelenik meg először. E két fogalom - természetesen más kontextusban - A tiszta ész kritikájának kulcsfogalmai közé tartozik, kidolgozásuk elôzményei pedig Hume filozófiájában találhatóak meg, egészen pontosan Humenak az észigazságokkal kapcsolatos fejtegetéseiben. A hume-i észigazságok pusztán elmebeli képzetek viszonyait testesítik meg, $\mathrm{s}$ jellemzójük a tapasztalattól való függet- 
lenség és szükségszerûség is. Az ilyen igazságok egyedül a geometria tételeit illetik meg, hiszen pl. Eukleidész tételei szükségszerúek, amennyiben ellenkezójüket nem tudjuk elképzelni, valamint akkor is igazak lennének, ha konkrétan egyetlen geometriai alakzat sem létezne.

Kant A tiszta ész kritikájában hasonló koncepciót vázol fel. Kiindulópontként az emberi megismerés két forrását az érzékiségben és az értelemben jelöli meg, s ezt követően szükségszerûség és egyetemesség az a priori, vagyis az érzéki benyomásoktól független, a tiszta "ismerő tehetségünkból" fakadó ismeretek két fontos tulajdonságát reprezentálja. Az a priori ítéletet egyrészt "szükségességével együtt" gondoljuk el, vagyis "más nem 'ehet", másrészt "szigorú általánossággal” gondoljuk el, tehát "kivétel alóla meg nem engedhetó" '. E két tulajdonság az a posteriori, vagyis az induktív tapasztalat által szolgáltatott ismeretekre nem vonatkozik, hiszen ezek csak azt mondják, hogy valami ilyen és ilyen, és hogy ezalól - legalábbis eddig - még nem találtak kivételt.

Kant szerint a hagyományos metafizika, miközben tárgyát az érzékfeletti világ dolgaiban jelöli meg, (pl. isten, szabadság, halhatatlanság) pont a fent említett a priori fogalmakból ismer meg, vagyis "a tapasztalatból nem merít semmit.” E metafizikával kapcsolatban azonban felmerül egy probléma, melynek forrása abban áll, hogy múvelôi nem pusztán az a priori fogalmak analitikus elemzésével - vagyis magyarázatával - foglalkoznak, hanem szintetikus a priori ítéletekkel bóvíteni is akarják ismereteinket. Ez a vállalkozás a metafizikusok elképzelései szerint nem ütközik nehézségekbe, Kant számára azonban túl merésznek bizonyul, amit többek között azzal is bizonyít, hogy a metafizika még nem vált tudománynyá, biztos ismereteket mindezidáig még nem tudott felmutatni. A metafizika így a dogmatizmus vádjával illethető, ti. azzal, hogy egyfajta elóitélet és elbizakodottság jellemzi, miszerint a tiszta ész "saját képességének megelőző kritikája nélkül"' is boldogulhat. Mivel azonban ez a hozzáállás eddig nem bizonyult gyümölcsözónek, Kant a metafizikában alkalmazott "tiszta ész" kritikájának alapos kidolgozását, "a tiszta észhasználat lehetségének" vizsgálatát javasolja.

Ennek alapjául $A$ tiszta ész kritikájában a kopernikuszi fordulat szolgál, melyból az a priori szemléleti formákon és értelmi kategóriákon keresztül a tárgy kétféle jelentéséhez (jelenség és magánvaló) vezet az út. Az e megkülönböztetéssel kapcsolatos fejtegetések végül azokat a metafizikára vonatkozóan sajátos megfontolásokat eredményezik, melyeknek lényege, hogy ismereterônkkel "sohasem léphetjük túl a lehetô tapasztalat határát, ami pedig e tudomány legfontosabb célja." " A metafizika csak a tapasztalatban megadható tárgyaknak megfelelő a priori fogalmak vizsgálatában, illetve a természet $a$ priori törvényeinek magyarázatában kompetens. Ez a konklúzió implicite magában foglalja a "kritika-tisztította" metafizika negatív hozadékát, amely mellett azonban fel kell figyelnünk az erkölcs tekintetében központi jelentőségú pozitív hozadékra is.

$\mathrm{Az}$ elóbbi arra figyelmeztet minket, ismerőerőnk korlátait megjelölve, hogy "a spekulatív ésszel ne merészkedjünk soha túl a tapasztalat határán"4 - márpedig természeti hajlandóságunk gyakran vezet erre az eredményre, kiváltképpen akkor, amikor a "feltétlent" akarjuk kutatni. Legvégső célját tekintve a tiszta ész általánosan "a gondolkodás legfelső egység alá vitelére”, konkrétan pedig a logikai következtetésekben a zárótételek általános föltételeinek, tehát a legfelsóbb egységnek a keresésére törekszik. Ekkor azonban a spekulatív ész minden a priori szintetikus ítéletével egy azonos mértékben bizonyítható ellentétel állítható szembe, vagyis antinómiákba botlunk. Kant magyarázata szerint mindez az ítélőtehetség hibájából történik, amely "a kategóriák empirikus használatán teljesen túlemel”. A priori fogalmainkat tehát kizárólag a tapasztalat tárgyaira, a jelenségekre alkalmazhatjuk - a metafizika csak a tapasztalat határain belül illetékes.

A "gondolkozásmód e fordulata" más- 
részról egy pozitív mozzanatot is magában hordoz. A szigorú értelemben vett metafizika feladása árán ugyan, de meggyőződhetünk az erkölcsök metafizikájának létjogosultságáról. Az ész gyakorlati használata ugyanis, az érzékiség határain túllépve, bizonyos értelemben választ adhat a feltétlen kutatása kapcsán felmerülő kérdéseinkre. $\mathrm{Az}$ erkölcs szükségképpen szabadságot tételez fel, de ha nem tennénk különbséget a tárgy mint jelenség és a tárgy mint magánvaló között, akkor a szabadság és szükségszerüség egy olyan antinómiában állna szemben egymással, amelyból nincs egyértelmü kiút. Mivel azonban a kopernikuszi fordulat révén e különbségtétel adott, mindez - a magánvaló dolgokat vizsgáló metafizika elutasítása mellett - a szabad akarat elgondolható képzetéhez, s ezáltal az erkölcs lehetőségéhez vezet.

A harmadik antinómiában mind a természet törvényei szerinti okság, mind a szabadság által való okság mellett szóló állítás bizonyítható. Ha tapasztalatunk tárgyai magánvaló dolgok lennének, akkor a természet önmagában kielégítő meghatározó oka lehetne mindennek, s nem lenne szükség szabadságra. A jelenség és a ma- gánvaló megkülönböztetése azonban lehetôvé teszi, hogy tézis és antitézis egyaránt igazságra tartson számot ${ }^{5}$, vagyis hogy e két tétel ne zárja ki egymást. Az embernek eszerint kétféle jelleme van. Empirikus jelleme abban áll, hogy cselekedetei mint jelenségek állandó természeti törvények szerint más jelenségekkel kapcsolatban vannak - intelligibilis jelleménél fogva azonban nem áll az érzékiség e föltétele alatt, hanem eszének öntevékenységével a jelenségek okaként szabad lénynek tekintendő.

A szabadság tehát a tiszta ész kritikájának pozitív hozadékaként elgondolható, bár valósága még nincs bizonyítva. A bizonyítás lehetôsége mindazonáltal fennáll, méghozzá a gyakorlati ész alaptételeinek, $\mathrm{s}$ leginkább az erkölcsi törvénynek a vizsgálata révén.

Kant az erkölcs legfóbb alaptételeit már A tiszta ész kritikájában a priorinak tekinti - amennyiben tehát ezek semmilyen empirikus elemet nem tartalmazó tiszta, vagyis univerzális és szükségszerú ismeretek -, mégsem tekinti az ezekkel kapcsolatos vizsgálódásokat a transzcendentális filozófia részének. Transzcendentális filozófiának a tárgyak a priori megismerési módjá-

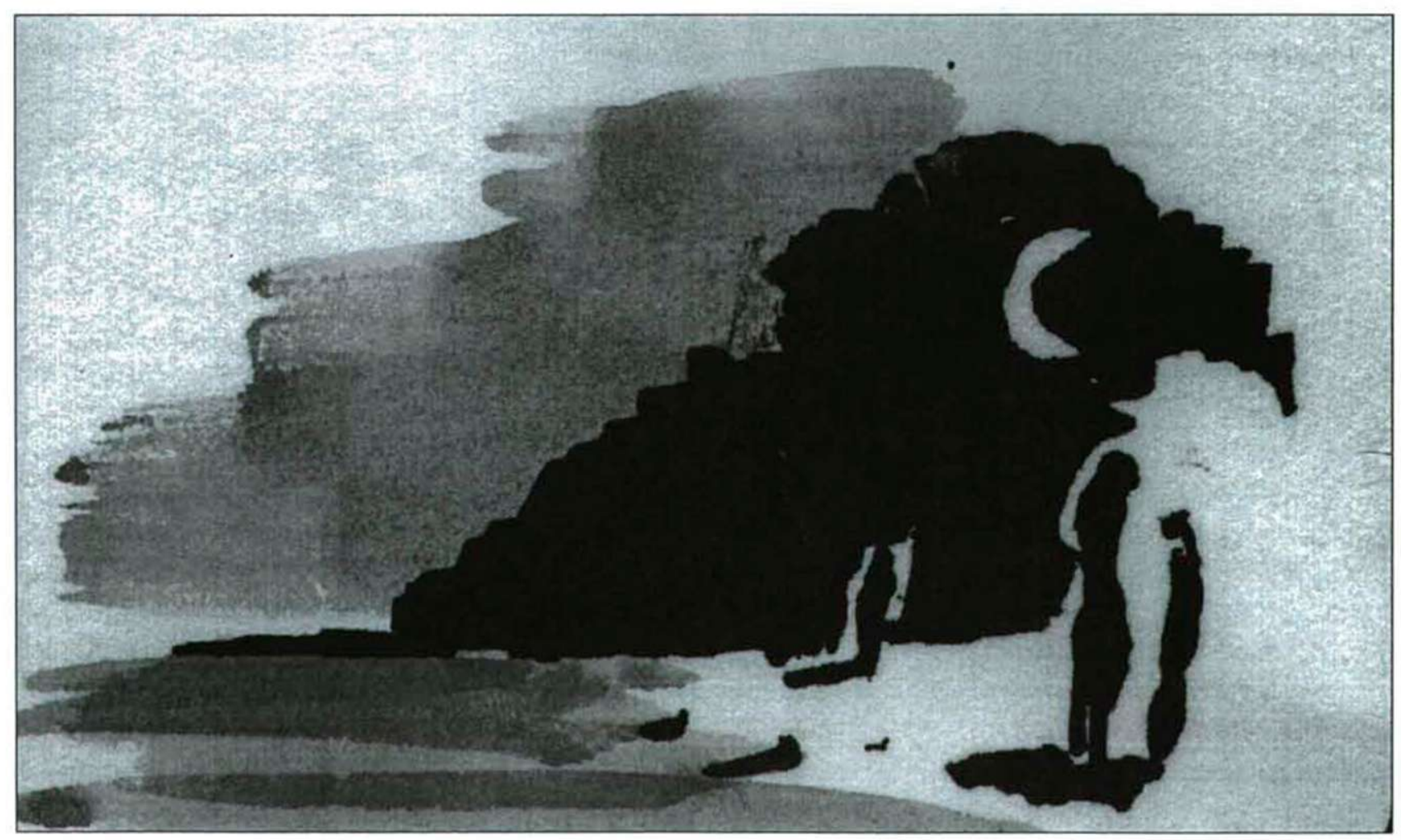


nak vizsgálata során elótérbe kerülő fogalmak rendszerét nevezi, s ide csak a tiszta spekulatív ész kritikája tartozik. Ennek oka az, hogy “az erkölcs legfóbb alaptételei ... a kín és a kéj, a vágyak s hajlamok fogalmát stb., melyek mind empirikus eredetúek, nem vetik ugyan szabályaiknak alapul, de mégis a kötelesség fogalmával mint legyőzendő akadályt vagy mint indító okul el nem fogadandó ingert szükségkép bevonják a tiszta erkölcsiség rendszerének szerkesztésébe."

$\mathrm{Az}$ erkölcsök metafizikája tehát annyiban metafizika, amennyiben alaptételei és fogalmai tiszta a priori jellegúek (tehát eltekint az emberi természet empirikus fogalmaitól, vagyis független minden antropológiától, mé ́ a gyakorlati antropológiától is $^{7}$ ), de nem transzcendentálfilozófia, hiszen nem csakis és kizárólag ezen tiszta fogalmak és tételek elemzésére irányul.

Összefoglalva azt mondhatjuk, hogy a tiszta ismeret és a tapasztalat viszonya a spekulatív ész kritikája során úgy jelenik meg, hogy a tapasztalat, a tapasztalásra való vonatkozás szükségessége az a priori megismerés feltételezésének folyománya, hiszen - mint ahogy a fentiekben utaltunk rá - a tapasztalat területének elhagyása egy kivételtól eltekintve feloldhatatlan ellentétekhez, antinómiákhoz vezet. A tiszta ész kritikájában az a priori ismeretek az érzéki benyomásokból szerzett ismeretekkel szoros kapcsolatban állnak, vagyis e kettő feltételezi egymást. Az etikában azonban az empirikus eredetű fogalmak az erkölcsi törvény megalapozása tekintetében elutasítandó alternatívákként merülnek fel, Kant az empíria minden szempontból történő kizárására tesz kísérletet. Ennek okait, melyekre a késóbbiekben még részletesebben visszatérünk, most röviden abban jelölhetjük meg, hogy a moralitás legfóbb elvét kutató tapasztalásból sohasem származhat semmiféle egyetemes érvényűség, pusztán általánosság, ez utóbbival azonban semmiképpen sem elégedhetünk meg abban az esetben, ha az erkölcsi törvényt univerzálisnak és szükségszerúnek feltételezzük.

Kant elött - az erkölcsi törvény forrását keresve - tehát pusztán két alternatíva áll: ez a forrás vagy a priori, vagy a posteriori, mivel azonban e törvény szerinte univerzális és szükségszerú érvényességgel rendelkezik, csak az a prioritás, vagyis a tiszta ész irányába indulhat el. Fejtegetései így mindenekelótt arra irányulnak, hogy kimutassák a tapasztalatnak az erkölcsi törvénnyel szemben minden vonatkozásban fennálló irrelevanciáját, ez a lépés pedig - mint ahogy Scheler kimutatja -, nem előfeltvésektól mentesen, de mégis egyenesen a formális erkölcsi törvény megfogalmazásához vezet.

$A z$ erkölcsök metafizikájának alapvetésében illetve A gyakorlati ész kritikájában Kant eltérő szempontokat figyelembe véve jut el ehhez a formalizmushoz, de a kiindulópont természetesen mindkét esetben azonos: a tiszta filozófia ideája, s ennek megfelelően mindenfajta materiális elv elutasítása.

\section{Az erkölcsök metafizikájának alapve- tése}

Kant tehát abból indul ki, hogy ha létezik erkölcsi törvény, akkor annak univerzálisnak és szükségszerünek kell lennie, vagyis e törvénynek bármely szituációban minden eszes lény számára - legyen az ember vagy valamilyen más teremtmény, éljen az bármely korban és bármilyen feltételek között a világegyetem bármely szegletében -, egyformán kötelezó érvényúnek kell lennie. Az Alapvetés előszavában ezt írja: "Mindenkinek el kell ismernie, hogy bármely törvénynek ahhoz, hogy erkölcsinek, vagyis kötelezettség alapjának számítson, abszolút szükségszerúséget kell tartalmaznia; hogy a ne hazudj! parancs nem csupán az emberekre érvényes, hanem más eszes lények sem hagyhatják figyelmen kívül, és ugyanígy áll a dolog az összes többi voltaképpeni erkölcsi törvénnyel ..." ${ }^{\text {8 }} \mathrm{Az}$ idézetból láthatjuk, hogy Kant az a priorinak tételezett erkölcsi törvényt, melyet a ne hazudj! paranccsal ${ }^{9}$ mutat fel, nem pusztán a saját, hanem minden egyes ember képzetének tekinti, vagyis úgy túnik, az erkölcsi 
törvény egyetemes szükségszerúsége minden egyes ember tudatában jelen van.

E kiindulópont kapcsán az Alapvetés szerkezetét, amelyet Kant három részre tagol, a következóképpen vázolhatjuk fel. Az első rész a közönséges erkölcsi észmegismerés, a második a népszerü erkölcsi életbölcsesség, a harmadik pedig az erkölcsök metafizikája. Ez utóbbira a szerző utalásai alapján nem csupán spekulatív, hanem egyben gyakorlati okok miatt is kell törekedni. A spekulatív okok mögött "a gyakorlati alaptételek forrásának kifürkészése”, a gyakorlati okok mögött pedig - az elóbbi törekvések eredményeit alapul véve - az "erkölcsök romlásának" megakadályozására irányuló szándék rèjlik.

Ross fejtegetései mindemellett feltárnak egy mélyebb összefüggést is az egyes "stádiumok” között. Eszerint az első részról a másodikra, onnan pedig a harmadikra való áttérésre nem azért van szükség, mert a közönséges erkölcsi megismerés vagy az ezután vizsgált népszerú erkölcsi életbölcsesség helytelen megállapításokat tartalmaz, hanem azért, mert bár az első típusú megismerés helyes, "nem eléggé mély", s ugyanez mondható el a másodikról is ${ }^{10}$. Így hát amikor Kant az erkölcsi törvénnyel szemben megfogalmazza követelményeit az univerzalitást és szükségszerúséget -, ezeket egyben a közfelfogásnak is tulajdonítja, mintegy megelözvén ezzel azokat az esetleges vádakat, amelyek szerint ez a gondolat az ő saját, érvekkel alá nem támasztott előfeltevése.

Első lépésként a közönséges erkölcsi észmegismerés kötelesség-fogalmát elemzi, hiszen a fenti idézet tanúsága szerint az erkölcsiség alapja a hétköznapi gondolkodásban is valamiképp e fogalomhoz kapcsolódik. Az elemzések során a szerző szándékai szerint fény derül arra, hogy mindenféle hajlam, a posteriori hajtóerő és mindenféle a posteriori cél alkalmatlan arra, hogy a cselekedet erkölcsi értékének letéteményese legyen.

A hajlam "a vágyóképességnek az érzékeléstól való függése" ${ }^{11}$, méghozzá mindig valamilyen szubjektív értelemben. A csele- kedet szempontjából a hajlam lehet közvetlen és közvetett is. Az első esetben a cselekedet ösztönzôje például az, hogy az egyén megóvja saját életét, de valakinek arra is lehet közvetlen hajlama, hogy kedves és segítókész legyen embertársaival, hogy szeresse óket stb. A második esetben az illető nem azért tesz vagy nem tesz meg valamit, mert erre hajlama van, hanem azért, mert másvalami ösztönzi, vagyis ezzel a cselekedettel valami mást érhet el. Például egy kereskedő azért is bánhat becsületesen az emberekkel, hogy megórizze vevókörét, amiból neki természetesen anyagi haszna is származik. Kant megítélése szerint az ilyen és az ehhez hasonló esetekben a cselekedetet az önző szándék vezérli.

A fenti példákból is kiderülhet, hogy az emberek nagymértékben különböznek atekintetben, hogy mire van hajlamuk, ezért ha ez a hajtóerő lenne a moralitás fundamentuma, akkor az erkölcsi törvény nem lehetne kivétel nélkül mindenki számára egyöntetűen univerzális szükségszerűséggel felruházva. Ha tehát a moralitás a hajlamokon alapulna, "lehetetlen lenne az egyezôség az emberek között a moralitás tekintetében, mivel minden individuum saját hajlamainak kielégítésére törekedne." 12 A jellem morális értéke ezért nem abban rejlik hogy hajlamból, hanem abban, hogy kötelességból cselekszik jót. ${ }^{13}$

Ha hajlamból cselekszünk, a fentiekból következően teljesen mindegy, hogy mit eredményez tettünk, nem lesz morálisan értékes - bármilyen hasznosnak és jónak is tûnjön az általa elért eredmény. Kant azonban nem áll meg ezen a ponton, hisz nem csupán a hajlamból elkövetett cselekedetek esetén tekint el a következményektól, hanem valójában mindenféle tett értékelésekor. Mindezt azért teszi, mert szerinte a cselekedet végeredményét figyelembe véve soha nem találhatunk egyetlen olyan a posteriori mozzanatot sem, amely feltétlen értékként a moralitás elvéhez vezetne: "a kötelességból való cselekedet morális értékét nem a szándék adja, amelyet általa el kell érni..."14 - írja. A szándék (Absicht) itt bármely materiális cél feltételezésére, illetve 
ennek megvalósulása kapcsán a hozzá kapcsolódó hasznosságra utal, az ezzel kapcsolatos fejtegetések pedig szoros összefüggésben állnak a jó akaratra vonatkozó megfontolásokkal, melyek az Alapvetés első szakaszának elején találhatók.

Kant a moralitás alapelvének fundamentumával kapcsolatos elvárásait itt úgy fogalmazza meg, hogy ennek nem csupán jónak, hanem "minden megszorítás nélkül jó"-nak kell lennie. Ross szerint az Alapvetés semmilyen vonatkozásban nem tartalmazza a jó fogalmának definícióját ${ }^{15}$, de ha figyelembe vesszük Kantnak az erkölcsi törvénynyel szemben kinyilvánított elvárásait, akkor az elsô szakaszból talán mégis kiolvashatjuk a "minden megszorítás nélkül jó" egy l hetséges értelmezését. Itt ugyanis a szellem adottságaira, a vérmérséklet tulajdonságaira, a szerencse adományaira Kant azt mondja, hogy ezek azért nem lehetnek "minden megszorítás nélkül jók", mert nincs "feltétlen belső értékük", vagyis nem lehet óket "tisztán jónak" (schlechthin gut) tartani. Bár ezen a helyen a szerző nem azt a kifejezést használja, amellyel az első Kritikában a tiszta észre, vagy a tiszta ismeretre utalt, mégis, a feltétlenség a szó szoros értelmében valamilyen megkérdójelezhetetlen, kétségbevonhatatlan értékre vonatkozik, olyanra, ami mindenki számára szükségszerú érvénnyel bír. Kant tehát a fenti terminus alatt is valami olyasmit érthet, ami univerzálisan és szükségszerüen jó.

$\mathrm{Ez}$ azonban azt jelenti, hogy ha valamit "minden megszorítás nélkül jónak" akarunk nevezni, akkor nem találhatunk olyan körülményt, amelynek fennállása esetén ez a valami nem jó. Márpedig Kant szerint mindenféle, eredetileg jónak minósített tartalomról, konkrét cselekvésról elmondható, hogy bizonyos szituációkban nem jó - mondjuk akkor, ha rossz akarattal párosul. Például az antik bölcsek által nagyrabecsült mértékletesség rossz akarattal együtt "hidegvérü gonosztevőt" eredményez. S ugyanígy, a mértékletességhez hasonlóan egyetlen konkrét cselekedet sem lehet feltétlenül és szükségszerúen jó, még akkor sem, ha sok szempontból jónak is ítéljük óket.

Ha tehát valami nem feltétlenül jó, akkor elófordulhat vele, hogy bizonyos esetekben rossz. Itt felmerülhet a kérdés, hogy mit ért Kant "rossz" alatt. A fent említett szövegben úgy tưnik, kétféle értelemben használja ezt a kifejezést. Egyrészt úgy, mint valami, ami "káros", "veszélyes", másrészt pedig úgy, mint valami, ami "megvetésre méltó”. Az első esetben a szóhasználat arra utal, hogy valamit annak alapján minósíthetünk rossznak, hogy milyen következményekkel, eredményekkel jár. A hidegvérű gonosztevő például az általános jólétet veszélyezteti ${ }^{16}$, vagyis cselekedetei mind az egyes egyén, mind a közösség érdekeire nézve káros következményekkel járnak. A második esetben úgy túnik, mintha valamiról önmagában, az általa okozott következményektól függetlenül is megállapíthatnánk, hogy rossz, tehát mintha eleve létezne egy olyan viszonyítási alap, amelynek segítségével valamit megvetésre méltónak ítélhetnénk. Sôt, ennek alapján mintha az értékek egymáshoz való viszonyáról is tájékozódhatnánk, hisz Kant nem pusztán azt írja, hogy a hidegvérú gonosztevő megvetésre méltó, hanem azt, hogy "a mi szemünkben megvetésre méltóbb is, mint amilyennek e tulajdonság nélkül tartanánk." ${ }^{17}$ Ennek ellenére mégsem beszél a materiális értékek hierarchiájáról, egy olyan hierarchiáról, melynek lehetósége a tartalmi etika híveinél ilyen vagy olyan formában, de megjelenik, hiszen a fenti fejtegetések alapján minden egyes ilyen tartalomnak, amelynek valamilyen értéket tulajdonítanánk, az értékmérő ellentétes oldalán megjelenne az a párja, amely rossz akarattal összekapcsolva mutatná fel ôt. Így pedig nem lehetne abszolút rangsorról beszélni, olyanról, amelyben a cselekedetek értéke mindenkor állandó és feltétlen abban az értelemben, hogy szükségszerú, tehát "más nem lehet”. Kant tehát úgy okoskodik a moralitás fundamentumának keresése közben, hogy egyetlen tartalmakra vonatkozó hierarchia sem töltheti be a "megszorítás nélküli jó” szerepét, mivel ez a hierarchia a 
rossz akarat jelenlétének lehetősége miatt sohasem lehet univerzális és szükségszerú.

Feltétlenül jó csak a jó akarat. Fontos azonban megjegyezni, hogy ez a fogalom nem csupán valamiféle passzív akarást foglal magába. Az akarás ugyanis a kanti etikában "nem mint puszta kívánság, hanem mint valamennyi, hatalmunkban álló eszköz mozgósítása" ${ }^{18}$ szerepel. Nem lehet tehát egy olyan személyt morálisan jónak nevezni, akinek akarása - megmaradván a tudat síkján - jó, de ez nem kapcsolódik semmiféle konkrét erófeszítésekhez, vagyis cselekvéshez. Az akarat Kantnál csakis a cselekvéssel összefonódva jelenik meg, így máris megkérdőjelezhetőek azok a kritikák, amelyek az akarat kihangsúlyozásában inaktivitást, cselekvóképtelenséget és ennek elfogadását, vagy minden kertelés nélkül egyszerüen "gyengeséget"19 látnak. Kant az akaratot a tettel kapcsolja össze, de azt mondja, hogy a cselekedet morális értéke "pusztán az akarás elvétól függ, amely szerint a cselekedet, a vágyóképesség összes tárgyától függetlenül, bekövetkezett." ${ }^{20}$

A hajlam és a materiális cél rövid áttekintése után most térjünk rá a kötelesség tárgyalására. Ezzel kapcsolatban Kant elöször is kifejti, hogy a kötelességszerü, vagyis a törvénynek megfelelö cselekedet nem tekinthető morálisan jónak. Ez a gondolat tulajdonképpen annak a fentebb említett elképzelésnek feleltethető meg, miszerint magát a cselekedetet attól, hogy az általa elért eredmény jó, még nem lehet morálisan jónak tekinteni. Csak az a cselekedet morálisan értékes, amelyet kötelességból, a törvény kedvéért hajtanak végre. Kant ebból kiindulva azt próbálja meg bizonyítani, hogy a hétköznapi megismerés nem téved, amikor a kötelesség fogalmával mutatja fel az erkölcsöt, vagyis hogy a kötelesség fogalma valóban az erkölcsi törvény fundamentumául szolgálhat. Ez pedig csakis úgy lehetséges, hogy erkölcsi szempontból az a cselekedet jó, amelyet kötelességból hajtanak végre, vagyis amit - és ez már Kant kötelesség-fogalmának sajátos értelmezéséból fakad - kizárólag az ész törvénye határoz meg, illetve ami az észtörvény iránti tiszta tiszteletból fakad.

A tisztelet nem tartalmaz semmiféle külső, empirikus mozzanatot. Bár érzésnek kell tekintenünk, ez mégis egy sajátos, "észfogalom alkotta érzés", melynek tárgya "csupáncsak a törvény, méghozzá az a törvény, amelyet saját magunknak szabunk, de mégis mint önmagában szükségszerút." ${ }^{21}$ Mivel pedig az ész az univerzális és szükségszerú parancsok forrása, ezért elérkeztünk az erkölcsi törvénynek ahhoz a kiindulópontjához, mely teljes mértékben kielégíti azokat a követelményeket, melyeket Kant már kezdettól fogva megfogalmazott velük szemben.

$\mathrm{Az}$ ész és az akarat egymáshoz való viszonyának, illetve az ebból fakadó formális erkölcsi törvénynek közelebbi vizsgálata elótt azonban érdemes röviden kitérni a kötelesség és a hajlam sajátos kapcsolatának interpretációjára.

Paton szerint ${ }^{22}$ gyakoriak azok a félreértések, amelyek azt állítják, hogy Kantnál a hajlam és a kötelesség olyannyira élesen szembeállnak, hogy ki is zárják egymást, vagyis abban az esetben, ha bármilyen hajlam jelen van az adott cselekedetre vonatkozóan annak végrehajtásakor, nem beszélhetünk kötelességról, e tett morális értékéról. Ez az értelmezés, melynek egyik közismert képviselôje Schiller, távol áll az eredeti kanti gondolatoktól, hiszen ez utóbbiak szerint a hajlam jelenléte nem zárja ki azt, hogy a cselekvő kötelessége végrehajtására törekedjen. Kant két szempontból állítja szembe a hajlamot és a kötelességet. Először is közülük csak az egyik lehet a morális cselekedet kiindulópontja: a kötelességból való cselekedetnek kell az akaratot tisztán meghatároznia, anélkül, hogy ebben bármilyen hajlam is szerepet játszana. Másodszor pedig a kötelesség végrehajtása sokszor a hajlamok kielégítésére irányuló törekvés feláldozását követeli meg. Ez azonban nem jelenti minden tekintetben a hajlamok elutasítását, sôt, Paton rámutat arra, hogy Kant bizonyos értelemben még egy sajátos funkcióval is felruházza óket, nevezetesen azzal, hogy az erényból fakadó 


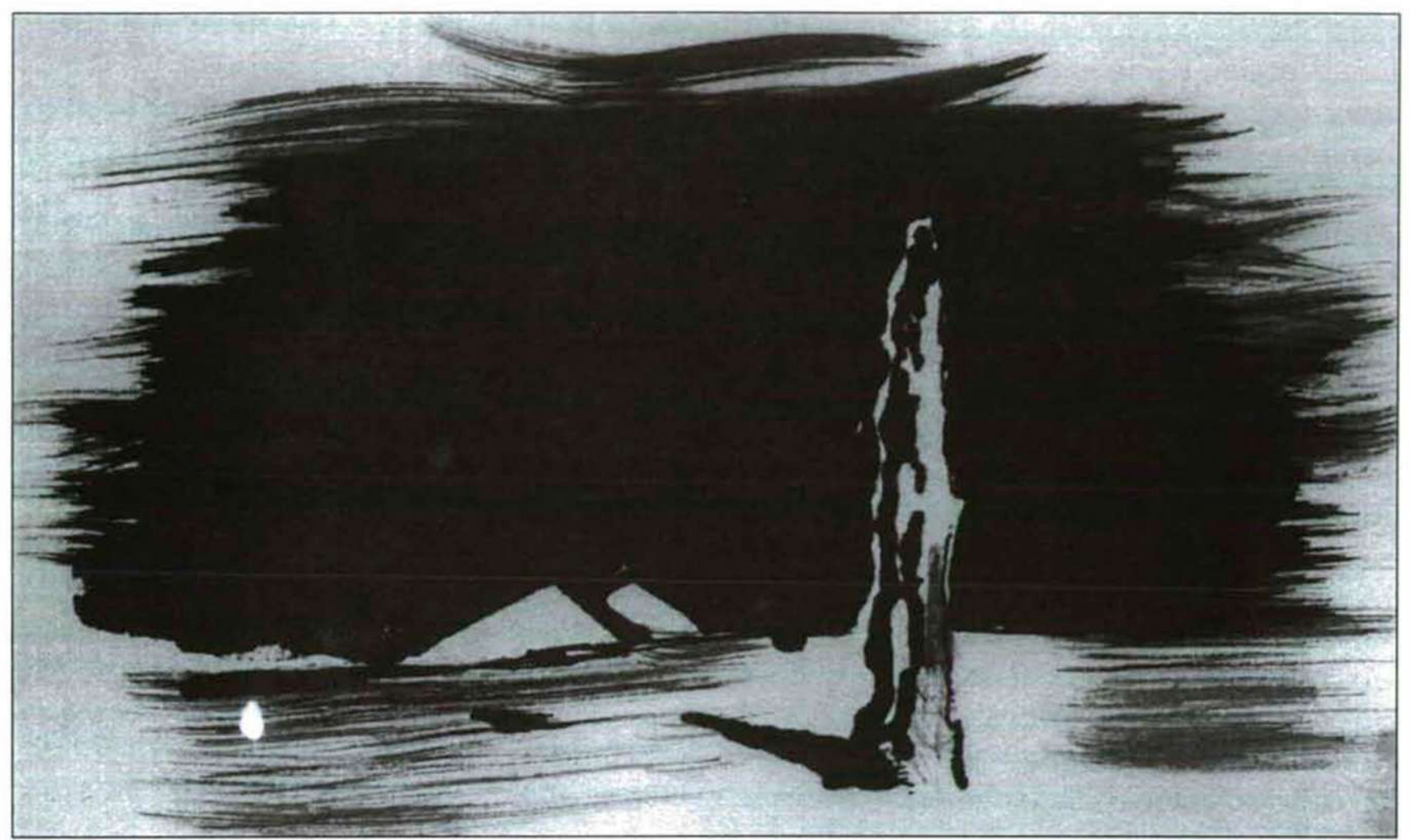

hasznok és a bünból fakadó hátrányok felmutatása révén "felkészítsék a tanulatlan elméket az erényes útra.” Az Alapvetésben ez a gondolat a cselekedet hasznosságával és terméketlenségével kapcsolatos fejtegetésekben is megjelenik. Mindkettő a jó akarat "foglalataként" szerepel, amely "megkönnyíti kezelését a közönséges érintkezésben, magára vonhatja azok figyelmét, akik még nem eléggé ismerik, arra azonban egyik sem alkalmas, hogy jó akaratot ajánljon a hozzáértóknek, és értékét meghatározza." ${ }^{23}$ (kiemelés - T.K.)

Visszatérve az erkölcsi törvény forrásához, melyet tehát Kant az észben talál meg, a formalizmus alappilléreit tovább kutatva a következő mozzanatokat kell figyelembe vennünk. Az ész az, ami felismeri, mi a jó méghozzá objektíve, általános érvénnyel, vagyis az erkölcsi törvénnyel szemben támasztott követelménynek megfelelöen -, és ezt mint gyakorlatilag szükségszerüt, mint követendőt állítja elénk. Ezt az ész által felismert objektív törvényt az akarat közvetíti számunkra. Az akarat mint gyakorlati ész révén vagyunk ugyanis képesek arra, hogy "törvények képzete, vagyis elvek alapján” cselekedjünk, hogy felfogjuk az észtör- vényeket és következtetéseket vonjunk le belólük a cselekedetekre vonatkozóan. Az ész azonban különféle szükségszerúségeket ír elő az akarat számára, s ezek közül nem mindegyik felel meg annak, amely az erkölcsi törvényben kell hogy megjelenjen - vagyis nem mindegyikben jelenik meg objektív és egyetemes érvényú szükségszerúség.

Az imperatívuszokat, melyek az ész által kinyilvánított szükségszerúségeket tartalmazzák, Kant a "parancsok formulái”-ként definiálja, ezért mielött rátérnénk az imperatívuszok tárgyalására, a parancs fogalma igényel rövid magyarázatot. Az ész előírásai az emberi akarat számára mindenkor parancsot jelentenek, mivel cselekedeteinkben akaratunkat nem kizárólag e racionális törvények határozhatják és határozzák meg, hanem más motívumok is, mint például ösztöneink, hajlamaink, vágyaink stb. Ez utóbbiak természetesen nem azonosak az ész által támasztott követelményekkel, ezért ha az erkölcsi törvénynek akarunk engedelmeskedni, amely tehát az empirikus tartalmaktól mentes tiszta észból ered, úrrá kell lennünk rajtuk, figyelmen kívül kell óket hagynunk. Így ąz erkölcsi törvény mint parancs kényszerítő jelleget 
ölt. Ez a kényszer abban mutatkozik meg, hogy az imperatívuszok mindig valamilyen "Legyenben" fejeződnek ki. ${ }^{24}$

$\mathrm{Az}$ erkölcsi törvény tehát, amelynek Kant elképzelése szerint szükségszerűnek és univerzálisnak kell lennie, az észból fakad, de nem minden észból fakadó előírás, parancs felel meg ennek a követelménynek. Vagyis, mint ahogy már említettük, az im. peratívuszokban megjelenő, az ész által gyakorlatilag szükségszerúnek tartott cselekedetek több szempontból lehetnek jók, de ezek közül csak egy esetben beszélhetünk az erkölcsi törvénynek megfelelố szükségszerûségról illetve jóságról.

$\mathrm{Az}$ imperatívuszok első típusa, a hipotetikus imperatívusz nem lehet univerzális és objektíve szükségszerü, ezért nem lehet erkölcsi törvény sem. A hipotetikus impera. tívusz mindazonáltal kétféle lehet: a jártasság és az okosság imperatívusza. Mindkettő valamilyen cél eléréséhez szükséges esz. közt ír elő számunkra. A jártasság imperatívusza egy tetszólegesen választott, lehetséges cél elérésére vonatkozik, ezért Kant problematikusnak nevezi óket ${ }^{25}$. Ha viszont már kiválasztottunk magunknak egy célt, ami ez esetben tehát bármi lehet, a hozzá vezető eszközök már eleve adottak. A gyakorlati élet szinte minden területén találhatunk ilyen imperatívuszokat (Kant ebból a szempontból fóleg a gyakorlati tudományokat emeli ki, pl. geometria, mechanika), amelyek formája a következő: 'Ha ez és ez a célod, ezt és ezt kell tenned'. Ha pl. egy háromszöget akarsz szerkeszteni, ennek meg. vannak a maga módszerei, vagy ha egy orvos ki akar valakit gyógyítani egy bizonyos betegségból, ennek is megvannak az ész által megparancsolt objektív eszközei. Az ilyenfajta imperatívuszok száma egy lehetséges szándékot feltételezve is végtelen, de mivel nem tartalmaznak semmiféle meg. fontolást a feltételezett cél jóságát illetően, nincs semmilyen etikai vonatkozásuk - a bennük felmerülő jóság csupán a kiválasztott cél és a hozzá vezető út ész által biztosított szükségszerű megfelelését tartalmazza. Ebben az esetben tehát csupán a hasznosság értelmében vett jóságról lehetne be- szélni. A jártasság imperatívuszának a "bonitas problematica"26 felel meg: valami azért jó, mert eszköz egy tetszóleges cél eléréséhez.

$\mathrm{Az}$ okosság imperatívuszánál a cél már nem tetszóleges, hanem mindenkiben valóságos (asszertorikus) és feltételezhetően azonos, méghozzá a boldogság elérése. Ezért az ilyen imperatívusz formája nem az, hogy 'Ha boldog akarsz lenni, ezt és ezt kell tenned', hanem ez: 'Mivel boldog akarsz lenni, ezt és ezt kell tenned'27. Ebben az esetben azonban az előzőektól eltérően nem pusztán a "cél elérésének módját" kell meghatározni, hanem magát a célt is, vagyis azt, hogy miben is áll a boldogság. Az okosság imperatívuszának a "bonitas pragmatica"28 felel meg: egy cselekedet azért jó, mert eszköz a boldogság eléréséhez.

A jártasság és az okosság imperatívuszának közös vonása az, hogy az ész által megkövetelt cselekedet mindkét esetben valami "másvalami miatt jó", s ez a "másvalami" olyan feltételt eredményez a hipotetikus imperatívuszban, amely kizárja az erkölcsi törvényhez szükséges objektív szükségszerüséget és univerzalizmust. A problematikus cél esetében azért teszi ezt, mert, mint ahogy a neve is utal rá, ez a "másvalami” csupán lehetséges és tetszóleges, vagyis vagy megjelenik az adott egyénben, vagy nem: például nem gondolható el, hogy kivétel nélkül mindenkiben egyformán jelen van a háromszög szerkesztésének szándéka, ebben az esetben azonban nincs értelme egy olyan törvénynek, amely kivétel nélkül mindenkinek megparancsolja, hogy vegyen a kezébe körzőt és vonalzót, s ezekkel az eszközökkel ilyen és ilyen mozdulatokat végezzen stb. Ezért is nevezi Kant a jártasság imperatívuszait a kényszerítés mértékét figyelembe véve "szabályok"-nak, mivel ezek bár világosak és határozottak is lehetnek, csak akkor vesszük hasznukat, ha egy bizonyos célt akarunk elérni. Itt tehát nem beszélhetünk az objektív szükségszerúség és univerzalizmus együttes megvalósulásáról. A mindenkiben feltételezett közös cél, vagyis a boldogság esetében azonban lehet szükségszerüségról és unj- 
verzalizmusról beszélni, de csak szubjektív értelemben ${ }^{29}$. Az adott cselekedetet szükségszerüvé tevő "másvalami”-ról alkotott elképzelés ugyanis nem lehet azonos minden eszes lényben. Az okosság imperatívuszai "tanácsok", amelyek a szabályokhoz képest határozatlanabbak lehetnek, de a boldogságra törekvés miatt a kényszerítés magasabb fokát tartalmazzák, hiszen az egyes egyén szempontjából ostobaság lenne nem törekedni a boldogságra ${ }^{30}$.

Úgy tưnik tehát, hogy az egyén által tételezett vagy tételezhető cél az, ami megakadályozza az erkölcsi törvényhez való eljutást. Kant ezért eltekint ezektól a korlátozó feltételektól, s így eljut az imperatívusz másik típusához, a kategorikus imperatívuszhoz, aı ely már kielégíti az erkölcsi törvénynyel szemben támasztott igényeit. Itt a cselekedet már magáértvalóan jó és szükségszerü, mindenféle céltól függetlenül pusztán egy Legyent tartalmaz ${ }^{31}$, vagyis a kategorikus imperatívuszban feltétlen, objektív és univerzális szükségszerúség fejeződik ki.

$\mathrm{Az}$ Alapvetés fejtegetései alapján azt mondhatjuk, hogy Kant nem pusztán egy meghatározott tartalmi elv vagy tartalmi elvek elutasítására törekszik, hanem arra, hogy a legfóbb gyakorlati elvból általában minden anyagi mozzanatot kizárjon. Ha ugyanis bármilyen konkrét matéria jelenne meg az erkölcsi törvényben, akár egy sajátos hajlam, akár egy elérendő cél mint mozgatórugó formájában, ezek vizsgálatához az egyes embereket kellene számba vennünk, méghozzá a közöttük fennálló különbségekkel együtt. Ehhez azonban - az emberi természet vizsgálata céljából - az antropológiához hasonlóan a tapasztaláshoz kellene folyamodnunk, márpedig az induktív tapasztalat sohasem eredményezhet univerzális megismerést, s így univerzális és szükségszerű elveket sem.

Visszajutottunk tehát kiindulópontunkhoz, mely szerint az erkölcsi alapelveket - a velük szemben támasztott követelmények miatt - a metafizika, illetve egy minden empirikus ismeretet mellőző tiszta morálfilozófia keretein belül kell kifejteni. Az "erköl- csi elveknek nem az emberi természet sajátosságain kell alapulniuk, hanem magukért valóan, a priori kell fennállniuk" - ez pedig azt jelenti, hogy "általában az eszes lény általános fogalmából kell levezetni”"32 óket, hisz bármilyen körülmények között, kivétel nélkül minden értelmes lényre érvényesnek kell lenniük.

A tapasztalásból fakadó elvek már a közönséges erkölcsi észmegismerés számára is pusztán esetlegességet jelentenek. Azzal, hogy a cselekedeteknek a tapasztalás során felismert következményeit, vagyis pusztán a törvénynek való megfelelést tesszük meg az erkölcsi törvény kiindulópontjának, nem juthatunk szükségszerüséghez. Ez a megfelelés ugyanis csak esetleges lehet, hiszen "más okok is elôidézhették, tehát nem volt hozzájuk szükség valamely eszes lény akaratára." ${ }_{33} \mathrm{Ha}$ azonban e megfelelésról mégis mint valamilyen akarat okozatáról kell beszélnünk, akkor sem mondhatjuk kivétel nélkül minden esetben, hogy a cselekedet morálisan jó, mivel előfordulhatnak olyan esetek is, amikor véletlen körülmények közrejátszása folytán erkölcstelen okok is jó eredményre vezetnek. A következmény és a jó akarat kapcsolatát vizsgálva pedig arra a megállapításra kell jutnunk, miszerint a jó akarattal az is megtörténhet, hogy "hiányzik belóle szándéka kivitelezésének képessége", illetve hogy rajta kívül álló okok miatt, a legnagyobb erófeszítések ellenére sem jár sikerrel. ${ }^{34}$

A következmények mérlegelésén alapuló empirikus elvek mellett az emberi természet megfigyeléséból származó princípiumokra sem támaszkodhatunk, hiszen általánosságukkal kapcsolatosan már a hipotetikus imperatívuszok korábbi elemzéséból kiderült, hogy ezekben a formulákban a hajlam tárgyának nincs feltétlen értéke, méghozzá két okból. Egyrészt azért, mert ha nem lennének bizonyos szükségleteink, melyeken hajlamaink alapulnak, ezeknek a tárgyaknak egyáltalán nem tulajdonítanánk értéket, tehát "amit a tetszés szerinti cél elérése érdekében szükséges megtennünk, azt önmagában esetlegesnek tekinthetjük, s a szándékot feladva, az előirást is 
mindenkor elvethetjük" ${ }^{35}$ Másrészt, ha mégis úgy gondolnánk, hogy van valami, amire mindenki egyformán törekszik, erról sohasem győződhetnénk meg a tapasztalás révén.

A tapasztalatból kiolvasható mindenféle materiális hajtóerô és cél kizárása után azonban nem marad más hátra Kant szerint, mint "az általában vett cselekedetek általános törvényszerúsége", $\mathrm{s} \mathrm{ez} \mathrm{az,} \mathrm{ami} \mathrm{az}$ erkölcsi törvényben, a kategorikus imperatívuszban az akarat elvének alapjául szolgál. A formális erkölcsi törvény ennek fényében nem valamilyen meghatározott cselekedetet ír elö, hanem - egyik megfogalmazásában - így hangzik: "sohasem járhatok el másként, mint úgy, hogy egyúttal akarhassam, hogy maximám általános törvénnyé váljék." ${ }^{\prime 36}$

Ez az imperatívusz, a hajlam tárgyainak feltételes értéke helyett egy abszolút értéket, méghozzá az emberiséget mint öncélt tartja szem elôtt, s ezzel egyrészt az erkölcsi törvény az iránta táplált "csodálatot" és "tiszteletet" igazolva az egyéni hajlamoknál valami magasabb rendü érték követését és megbecsülését állítja elénk, másrészt pedig biztosítja azt az univerzális szükségszerúséget, melyet Kant szerint mindezideáig egyetlen elv sem volt képes felmutatni. A kérdés most már az, miként történik meg mindez, vagyis hogyan képes a königsbergi filozófus szerint a kategorikus imperatívusz - zárójelezve a különböző megfogalmazások között kimutatható tartalmi eltéréseket - az erkölcsi törvénnyel szemben támasztott követelményeket kielégíteni.

$\mathrm{Az}$ univerzális szükségszerúséget az ellentmondás-menetesség követelménye hivatott biztosítani, vagyis itt újra felelevenedik az az elvárás, amely a teoretikus ésszel szemben egyszer már megnyil-

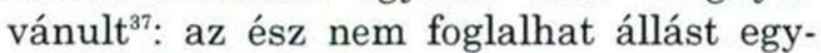
szerre két, egymással ellentétes ítélet mellett. Ez volt az a mozzanat, amely az antinómiák felmutatása után $A$ tiszta ész kritikájában a megismerés korlátainak meghatározásához vezetett, most pedig az erkölcsi törvény alapjául szolgál.
Az ellentmondás kizárásának szükségessége két aspektusban jelenik meg a moralitás legfóbb elvével kapcsolatosan. $\mathrm{Az}$ egyik az, hogy a cselekvő maximája az általános törvény formájára emelve ne foglaljon magába önellentmondást. Erre a lehetőségre a hazug ígéret maximája szolgálhat példaként, mivel ez általános törvényként nem gondolható el ellentmondás nélkül: "ha általánossá válnék egy olyan törvény, hogy bárki, ha úgy véli, szorult helyzetbe került, ígérhet bármit, ami csak eszébe jut, hiszen úgysem áll szándékában megtartani, ezzel maga az ígéret mint olyan, s vele a cél, amit szolgálhat, válna lehetetlenné. Hiszen senki sem hinné el, hogy ígértek neki valamit; mint hiú ürügyet ítélne meg minden ilyen megnyilvánulást." ${ }^{{ }^{38}} \mathrm{~A}$ törvényben szereplő cél, és az ennek elérésére szolgáló eszköz ellentmondanak egymásnak, ezért a maximát el kell vetni.

A másik esetben nem maga a törvény, hanem az univerzalizált maxima akarása lenne ellentmondásos, mivel a cselekvő - ha racionálisan gondolkodik - nem akarhatja, hogy a törvény vele szemben is érvényesüljön. Ilyen például a segítségnyújtás esete: senki sem akarhatja, hogy a mások felé irányuló segítségnyújtás megtagadását célzó maxima univerzális törvény legyen, még akkor sem, amikor valakinek "jól megy a sora", hiszen ezzel "megfosztanánk magunkat a kívánt segítség minden reményétól” arra az esetre vonatkozóan is, amikor mi magunk kerülünk bajba. Ha tehát a cselekvő képes maximáját általános törvény formájában akarni, akkor ezzel Kant szerint kizár a törvényból mindenfajta kivételt, amely megakadályozhatná az egyetemes érvényüség fennállását. Egy törvény ugyanis csak akkor lehet univerzális, ha akarója saját magával szemben is végrehajtandó kötelességnek tekinti, tehát ha nem akarja, hogy vele szemben bárki is kivételt tegyen - ellenkező esetben csupán a törvény általánosságáról lehet csak beszélni.

Kant úgy gondolja, hogy a kategorikus imperatívuszban megjelenik az a feltétlen és univerzális szükségszerúség, melyet $\mathrm{az}$ 
erkölcsi törvénnyel szemben már a kezdet kezdetén megfogalmazott, s hogy mindkét fenti esetben azokat a cselekedeteket zárja ki az erkölcsi törvényból, amelyek erkölcsi értelemben rosszak.

A kategorikus imperatívusszal fémjelzett kanti etika formalizmusával szemben azonban már számos kritika fogalmazódott meg. Hegel például a kategorikus imperatívusz használhatatlan, üres és semmitmondó jellegéból kiindulva indít támadást a formalizmus ellen, Scheler pedig a formális erkölcsi törvényhez vezető kanti gondolatmenet előfeltevéseit tárja fel és ezeket állítja kritikájának középpontjába.

Befejezésül kísérletet kell tennünk arra, hogy megválas oljuk a kérdést, miért is indult ki Kant az univerzális és szükségszerü törvény követelményéból, abból a követelményból, amely végül a kategorikus imperatívusz megfogalmazásához vezetett.

A választ azokban a megjegyzésekben is kereshetjük, amelyek arra utalnak, hogy az erkölcsi törvénynek minden egyes ember "hatalmában kell állnia"; olyan erkölcsi parancsot kell megfogalmazni, amelyet mindenki könnyen beláthat és aminek mindenki, ha nem is könnyen, de eleget tud tenni. A jó cselekedetek kivitelezése ne csak azok számára legyen lehetséges, akik sajátos hajlamokkal, különleges "fizikai képességekkel" vagy "nagy adag okossággal" stb. rendelkeznek, hanem mindenki számára. Ezt az elvárást Kant úgy próbálja megvalósítani, hogy eltekint az emberek között fennálló összes különbségtól, s az erkölcsi törvény megfogalmazásakor a jóság kritériumául pusztán az ellentmondás-mentesség - szerinte - egyszerú és problémamentes alkalmazását követeli meg, amely szándékai szerint már önmagában garancia a jó akaratra.

A tiszta ész kritikájában megfogalmazott előfeltevések - az erkölcsi törvény univerzális szükségszerúsége és a megismerés pusztán két, a priori és a posteriori alternatívája - az erkölcsiséghez elengedhetetlen szabadság feltételezése mellett szükségképpen egy formális erkölcsi törvény felmutatásá- hoz vezettek. A formális etika kiindulópontjául szolgáló követelmény (univerzális és szükségszerű erkölcsi törvény) mögött egy "demokratikus etika" ${ }_{40}$ igénye állt, amelynek álláspontjáról elutasíthatjuk, hogy az erkölcsös élet a - bármilyen értelemben vett - kiváltságosok privilégiuma, és emellett még saját magunkat, a racionális embert is méltónak tarthatjuk arra, hogy a legfóbb törvény fundamentuma legyen. Mégis úgy tûnik, ez a sajátos követelmény a priori és a posteriori következetesen végigvitt ellentétével olyan formális törvényhez vezetett, amely az ellentmondás-mentesség követelményében felmutatott racionalitás és az "ember mint öncél" magasztos eszméje ellenére sem képes olyan iránytüként szolgálni, mely eligazít minden olyan cselekvôt, aki az értékkonfliktusokkal szembekerülve erkölcsi támaszpontot keres.

\section{Irodalomjegyzék:}

KANT, Immanuel: Lectures on Ethics. ford. Louis Infield, Harper (Row, New York, 1963.)

KANT, Immanuel: A tiszta ész kritikája. ford. Alexander Bernát és Bánóczi József, Akadémiai Kiadó, Budapest, 1981.

KANT, Immanuel: Az erkölcsök metafizikájának alapvetése. ford. Berényi Gábor, Gondolat Kiadó, Budapest, 1991.

KANT, Immanuel: $A z$ itélốerố kritikája. ford. Hermann István, Akadémiai Kiadó, Budapest, 1979.

Aszmusz, V. F.: Immanuel Kant. 6. fej. Gondolat Kiadó, Budapest, 1982.

BECK, Lewis White: A Commentary on Kant's Critique of Practical Reason. University of Chicago Press, 1960.

Heller, Ágnes: Kant etikái. in: Portrévázlatok az etika történetéból. Gondolat Kiadó, Budapest, 1976. 212-288.o.

Paton, Herbert J.: The Categorical Imperative. A Study in Kant's Moral Philosophy. New York, Harper (Row, 1965.)

Ross, William D.: Kant's Ethical Theory. A Commentary on the Grundlegung zur Metaphysik der Sitten. Oxford, at the Clarendon Press, 1962.

Tengelyi, László: Kant. Kossuth Könyvkiadó, 1988.

WaLL, George B.: Introduction to Ethics. Chap. 4., Charles E Merrill Publishing 
Columbus, Ohio 1974.)

${ }^{1}$ Immanuel Kant: A tiszta ész kritikája. Akadémiai Kiadó, Budapest, 1981. 29. o.

${ }^{2}$ Id. mü 23. o.

${ }^{3}$ Id. mü 15 . o.

${ }^{4}$ Id. mú 17. o.

${ }^{5}$ Tengelyi László: Kant. Kossuth Könyvkiadó 1988. 109. o.

${ }^{6}$ Immanuel Kant: A tiszta ész kritikája. id. k. 43. o.

${ }^{7}$ Lewis White Beck: A Commentary on Kant's Critique of Practical Reason. University of Chicago Press, 1960. 7. o.

${ }^{8}$ Immanuel Kant: Az erkölcsök metafizikájának alapvetése (a továbbiakban: Alapvetés). Gondolat Kiadó, Budapest, 1991. 15. o.

${ }^{9}$ Ross szerint ez a parancs nem tisztán a priori, hanem "inkább abba a típusba tartozik, amit Kant $A$ tiszta ész kritikájában úgy nevez, hogy a priori, de nem tiszta a priori." Vagyis ez a parancs a "Minden változásnak megvan a maga oka" tételhez hasonlít, ahol is a változás fogalma a tapasztalatból származik. Ross érvelése szerint a hazugság fogalmához sem juthatunk el, ha csupán egy morális cselekvő ill. általában a tiszta akarat eszméje lebeg elöttünk. Ahhoz, hogy e fogalmat megkapjuk, egy "megtestesült akaratot", egy olyan cselekvőt kell figyelembe venni, aki "másokkal képes kommunikálni és hitet tud kialakítani bennük." Vagyis a hazugság fogalma is tartalmaz egy olyan elemet, amely a tapasztalatból származik. in: W. D. Ross: Kant's Ethical Theory. A Commentary on the Grundlegung zur Metaphysik der Sitten. Oxford, at the Clarendon Press, 1962. 2. o.

${ }^{10}$ Id. mú. 6-7. o.

${ }^{11}$ Immanuel Kant: Alapvetés. id.k. 43. o. lábjegyzet.

${ }^{12}$ Immanuel Kant: Lectures on Ethics. (ford. Louis Infield) New York, Harper (Row, 1963. 38. o.) Idézi: George B. Wall: Ethical Formalism. in: Introduction to ethics. Charles $\mathrm{E}$ Merrill Publishing Company, a Bell (Howell Company, Columbus, Ohio 1974. 75. o.)

${ }^{13}$ Immanuel Kant: Alapvetés. id.k. 26. o.

${ }^{14}$ Id.mü 27. o.

15 W. D. Ross: Kant' Ethical Theory. A Commentary on the Grundlegung zur Metaphysik der Sitten. id.k. 9. o.

${ }^{16}$ Id.mü 10. o.

${ }^{17}$ Immanuel Kant: Alapvetés. id.k. 21. o.

${ }^{18}$ Uo.

${ }^{19}$ V. F. Aszmusz: Immanuel Kant. Gondolat, Budapest, 1982. 289. o.
${ }^{20}$ Immanuel Kant: Alapvetés. id.k. 21. o.

${ }^{21}$ Id.mü 29. o. lábjegyzet.

${ }^{22}$ H. J. Paton: The Categorical Imperative. New York, Harper (Row, 1965. 48-50. o.)

${ }^{23}$ Immanuel Kant: Alapvetés. id.k. 21-22. o.

${ }^{24}$ Paton szerint Kant a továbbiakban nem használja fel a parancs és az imperatívusz között fentebb meghatározott különbségtételt, ezért ettól a késóbbiek során el lehet tekinteni. H. J. Paton: The Categorical Imperative. id.k. 114. o.

${ }^{25}$ A "problematikus imperatívusz" kifejezést Kant a harmadik Kritikában ellentmondásosnak minősíti. Immanuel Kant: Az ítélôerố kritikája. Akadémiai Kiadó, Budapest, 1979. 85. o. lábjegyzet.

${ }^{26}$ Immanuel Kant: Lectures on Ethics. id.k. 15. 0.

${ }^{27}$ Id. mú 5 . o.

${ }^{28}$ Id. mü 15.0.

${ }^{29}$ Id. mü 5. o.

${ }^{30}$ H. J. Paton: The Categorical Imperative. id.k. 116. o.

${ }^{31}$ Annak ellenére, hogy itt a cél tételezésére vagy nem tételezésére esik a hangsúly, nem szabad azt gondolnunk, hogy a kétfajta imperatívusz közti különbség a parancsok grammatikai vagy logikai formulájának vizsgálata révén is egyértelmüen megmutatkozik. Vannak ugyanis olyan hipotetikus (ha... akkor...) formában megfogalmazott parancsok, amelyek morálisan érvényesek, pl. "Ha megígérted, hogy viszszaadod a könyvet, akkor tégy is úgy"; ugyanakkor léteznek olyan kategorikus formában megfogalmazott parancsok, amelyek semmiféle morális tartalommal nem bírnak, pl. "Csukd be az ajtót". In: Lewis White Beck: $A$ Commentary on Kant's Critique of Practical Reason. id.k. 88. o.

${ }^{32}$ Immanuel Kant: Alapvetés. id.k. 40. o. lábjegyzet és 42 . o.

${ }^{33}$ Id. mú 29. o.

${ }^{34}$ Id. mü 21. o.

${ }^{35}$ Id. mü 51. o.

${ }^{36}$ Id. mü 30. o.

${ }^{37}$ George B. Wall: Ethical Formalism. in: Introduction to Ethics. id.k. 85. o.

${ }^{38}$ Immanuel Kant: Alapvetés. id.k. 54. o.

${ }^{39}$ Id. mü 55. o.

${ }^{40}$ Heller Ágnes: Kant etikái. in: Portrévázlatok az etika történetéból. Gondolat Kiadó, Budapest, 1976. 227. o. 